\title{
Upgraded Algorithm for Calculating the Turbo- Expander of Gas Distribution Stations
}

\author{
Mikhail Chekardovskiy ${ }^{1}$, Sergey Chekardovskiy ${ }^{1, *}$, Konstantin Ilyukhin ${ }^{1}$, and Alexey \\ Gladenko $^{1}$ \\ ${ }^{1}$ Industrial University of Tyumen, 625001 Volodarskogo str. 38, Tyumen, Russia
}

\begin{abstract}
The article deals with the urgency of adapting computational turbo-expander unit parameters techniques to the conditions of their application at gas distribution stations. Existing computational methods based on the use of air as the working medium yield incorrect data to determine the actual design parameters for operating conditions where the working medium is natural gas. A modernized algorithm of thermogasdynamic calculation of turbo-expanders in order to form the correct initial data for design calculations has been proposed. The objective of calculating turbo-expanders is to identify thermogasdynamic parameters and dimensions of the flow channel, rotational speed, and shaft power. Procedure of thermogasdynamic calculations is shown on the example of a turbo-expander running on natural gas. The result will simplify the process of selecting or designing turbo-expander units for gas distribution stations.
\end{abstract}

\section{Introduction}

Currently, obtaining electrical energy using resource-saving, environmentally friendly technologies becomes relevant. One of these areas is using the potential energy of highpressure natural gas from main gas pipelines with the use of turbo-expander units (TEU). It is known that at gas distribution stations (GDS) and gas control units (GCU) natural gas is reduced. In this case, the potential energy of the compressed gas is lost permanently which can be used to generate electricity and cooling.

For several decades, many European countries (Italy, Germany, etc.) have successfully been using this technology, installing TEU at GDS and GCU pipelines to reduce the gas pressure to the desired pressure for the consumer, both serving as GDS and GCU and simultaneously generating electricity. Wherein the gas is not burned but is used only as a working medium, moving further to the consumer. Thereafter, fuel combustion products do not pollute the environment.

\section{Research}

The process of gas expansion in the TEU is accompanied by an increase in its temperature. Therefore, in order to prevent hydrate formation, as well as to meet the SNIP temperature standards, at the TEU input gas heating is provided.

\footnotetext{
* Corresponding author: $\operatorname{ldgtd} @$ mail.ru
} 


\section{TPACEE-2016}

When designing the TEU at the GDS located in the energy-deficient regions, it is advisable to build a gas turbine power plant (GTP) next to the GDS. Combining a turboexpander with a heat exchanger of the power plant gas turbine engine which is intended for heating the natural gas at the inlet of the TEU will allow the production of electricity by this complex with a performance coefficient from 65 to $75 \%[1,7,8]$. Therefore, studies aimed at improving the TEU design techniques at GDS are connected with Energy Saving Strategy of Russia and are relevant.

The objective of calculating turbo-expanders is to identify thermogasdynamic parameters and dimensions of the flow channel, rotational speed, shaft power. Procedure of thermogasdynamic calculations is shown on the example of a turbo-expander running on natural gas.

Turbo-expanders of gas distribution stations (GDS) are used to generate electricity by natural gas differential pressure on the turbine stage. Approximate composition and characteristics of the components of natural gas transported through the main gas pipeline and entering the GDS are presented in Table 1.

Table 1. Composition and characteristics of the natural gas components.

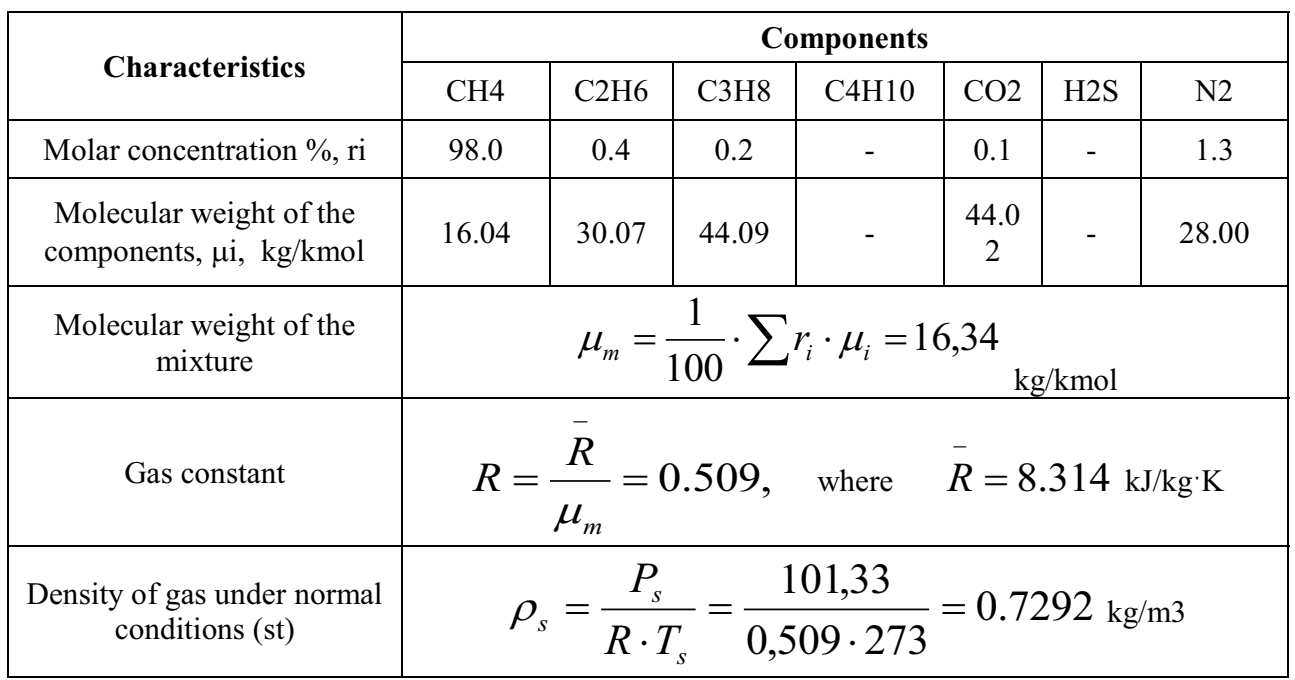

Table 2 shows sample GDS initial data.

Table 2. Main GDS initial data.

\begin{tabular}{|c|c|c|c|}
\hline Title & \multicolumn{2}{|c|}{ Value } & Note \\
\hline Gas pressure at the inlet & $\mathrm{PI}=45 \mathrm{~kg} / \mathrm{cm}$ & $4410 \mathrm{kPa}$ & $\begin{array}{c}\text { Density of gas } \\
\text { under normal } \\
\text { conditions } \\
\rho s t= \\
0,73 \mathrm{~kg} / \mathrm{m} 3\end{array}$ \\
\hline $\begin{array}{c}\text { Gas pressure at the outlet } \\
\begin{array}{c}\text { Gas flow rate through the } \\
\text { GDS }\end{array}\end{array}$ & $\mathrm{VO}=340$ thousand $\mathrm{n} \cdot \mathrm{m} 3 / \mathrm{h}$ & $\mathrm{M}=69.01 \mathrm{~kg} / \mathrm{s}$ & \\
\hline $\begin{array}{c}\text { Gas temperature at the inlet } \\
\text { Index of adiabatic gas } \\
\text { expansion }\end{array}$ & $\mathrm{tI}=35^{\circ} \mathrm{C}$ & $\mathrm{TI}=308 \mathrm{~K}$ & \\
\hline
\end{tabular}

Using the initial data in Tables 1 and 2, we made an upgraded algorithm for thermogasdynamic calculation of a turbo-expander in order to form correct input data for design calculations:

1. Gas temperature at the GDS outlet $[2,9,10], \mathrm{K}$ : 


$$
T_{\text {OUT }}=T_{I N} /\left(\frac{P_{I N}}{P_{\text {OUT }}}\right)^{\frac{K_{I}-1}{\mathrm{~K}_{\Gamma}}}
$$

2. Average heat capacity of natural gas [3], $\mathrm{kJ} / \mathrm{kg} \cdot \mathrm{K}$ :

$$
C_{P g_{1}}=\left(0,66+0,34 \cdot \frac{r_{C H_{4}}}{100}\right) \cdot\left[\left(0,00344-0,00009 \cdot P_{I N}\right) \cdot\left(\frac{t_{I N}+t_{O U T}}{2}\right)+0,011 \cdot P_{I N}+2,06\right](2)
$$

3. Available capacity of the GDS, $\mathrm{kW}$ :

$$
N_{G D S}=M \cdot C_{P_{2} 1} \cdot\left(T_{I N}-T_{\text {OUT }}\right)
$$

\begin{tabular}{|c|c|c|c|}
\hline Title & \multicolumn{2}{|c|}{ Value } & Note \\
\hline Gas pressure at the inlet & $\mathrm{P} 1=40 \mathrm{~kg} / \mathrm{cm} 2$ & $3920 \mathrm{kPa}$ & Density of gas \\
\hline Gas pressure at the outlet & $\mathrm{P} 2=9 \mathrm{~kg} / \mathrm{cm} 2$ & $882 \mathrm{kPa}$ & under normal \\
\hline Gas flow rate & 130 thousand $n \cdot m 3 / h$ & $26,386 \mathrm{~kg} / \mathrm{s}$ & conditions \\
\hline Gas temperature at the inlet & $\mathrm{t} 1=90^{\circ} \mathrm{C}$ & $\mathrm{T} 1=363 \mathrm{~K}$ & $\rho \mathrm{st}=0,73 \mathrm{~kg} / \mathrm{m} 3$ \\
\hline Gas temperature at the outlet & $\mathrm{t} 2=10^{\circ} \mathrm{C}$ & $\mathrm{T} 2=283 \mathrm{~K}$ & \\
\hline
\end{tabular}

As an example, table provides data on the TEU.

Table 3. Initial data on the turbo-expander.

4. Average heat capacity of natural gas $[3,11,12], \mathrm{kJ} / \mathrm{kg} \cdot \mathrm{K}$ :

$$
C_{P_{g_{2}}}=\left(0,66+0,34 \cdot \frac{r_{C H_{4}}}{100}\right) \cdot\left[\left(0,00344-0,00009 \cdot P_{1}\right) \cdot\left(\frac{t_{1}+t_{2}}{2}\right)+0,011 \cdot P_{1}+2,06\right]
$$

5. Available capacity of the GDS, $\mathrm{kW}$ :

$$
N_{T D}=M \cdot C_{P_{2}} \cdot\left(T_{1}-T_{2}\right)
$$

6. Joule-Thomson coefficient, which is a function of pressure, temperature and gas composition, $\mathrm{kJ} / \mathrm{kg} \cdot \mathrm{MPa}[4,13,14]$ :

$$
\left(C_{P} D_{i}\right)_{m}=10 \cdot\left(1,98-\frac{r_{C H_{4}}}{100}\right) \cdot\left[\left(0,0000012 \cdot t_{1}^{2}-0,000135 \cdot t_{1}+0,00298\right) \cdot P_{A}-0,00463 \cdot t_{1}+1,119\right](6)
$$

7. Enthalpy change considering the Joule-Thomson coefficient, $\mathrm{kJ} / \mathrm{kg}$ :

$$
\Delta h_{s}=C_{P_{2}} \cdot\left(T_{1}-T_{2}\right)-\left(C_{p} D_{i}\right)_{m} \cdot\left(P_{1}-P_{2}\right)
$$

8. Actual capacity of the TEU, $\mathrm{kW}$ :

$$
N_{T D A}=M \cdot \Delta h_{s}
$$

To realize the available capacity of the GDS it is expedient to install two turboexpanders with a capacity of $4000 \mathrm{~kW}$ each.

Let us specify the natural gas parameters by the technique formulas developed by "Gazprom VNIIGAZ", Moscow:

9. Density of gas under standard conditions, $\mathrm{kg} / \mathrm{m} 3$ : 


$$
\rho_{S T}=\frac{P_{S T}}{R \cdot T_{S T}}
$$

where: standard pressure $\mathrm{P}_{\mathrm{ST}}=101.33 \mathrm{kPa}$ and temperature $\mathrm{T}_{\mathrm{ST}}=293 \mathrm{~K}$

10. Critical gas pressure, MPa:

$$
\mathrm{P}_{\mathrm{CR}}=0,1773\left(26,831-\rho_{\mathrm{ST}}\right)
$$

11. Critical gas temperature, $\mathrm{K}$ :

$$
\mathrm{T}_{\mathrm{CR}}=156,24\left(0,564+\rho_{\mathrm{ST}}\right)
$$

12. Reduced value of gas pressure:

$$
P_{R}=\left(P_{1}+P_{2}\right) / 2 P_{C R}
$$

13. Reduced value of gas temperature:

$$
T_{R}=\left(T_{1}+T_{2}\right) / 2 T_{C R}
$$

14. Let us find $\tau[5,15,16]$ :

$$
\tau=1-1,68 \mathrm{~T}_{\mathrm{R}}+0,78 \mathrm{~T}_{\mathrm{R}}^{2}+0,0107 \mathrm{~T}^{3}{ }_{\mathrm{R}}
$$

15. Let us define the gas compressibility factor, in a case if a TEU worked as centrifugal gas blower (that is, compressed gas) [6, 17, 18 etc]:

$$
Z=1-0,0241 \frac{P_{R}}{\tau}
$$

16. Available potential work of a turbo-expander, $\mathrm{kJ} / \mathrm{kg}$ :

$$
\omega=Z \cdot R \cdot\left(\frac{T_{1}+T_{2}}{2}\right) \cdot \ln \frac{P_{1}}{P_{2}}
$$

17. Available potential capacity of a TEU, $\mathrm{kW}$ :

$$
N_{G D S}=M \cdot \omega
$$

18. Polytropic performance efficiency of a turbo-expander $[19,20]$ :

$$
\eta_{P}=\frac{\Delta h}{\omega}
$$

Sample calculation results are summarized in Table 4 .

\section{Conclusion}

Application of a TEU at the GDS produces electricity due to the pressure difference at the input and output of the unit. 
Table 4. Calculation results.

\begin{tabular}{|c|c|c|c|}
\hline № & Parameter symbol & $\begin{array}{c}\text { Unit of } \\
\text { measurement }\end{array}$ & Value \\
\hline 1 & TOUT & $\mathrm{K}$ & 246.76 \\
\hline 2 & Cpg1 & $\mathrm{kJ} / \mathrm{kg} \cdot \mathrm{K}$ & 2.12 \\
\hline 3 & NGDS & $\mathrm{kW}$ & 8877.7 \\
\hline 4 & Cpg2 $/ \mathrm{kg} \cdot \mathrm{K}$ & 2.235 \\
\hline 5 & NTD & $\mathrm{kW}$ & 4717.6 \\
\hline 6 & CpDi & $\mathrm{kJ} / \mathrm{kg} \cdot \mathrm{MPa}$ & 7.036 \\
\hline 7 & $\Delta \mathrm{hs}$ & $\mathrm{kJ} / \mathrm{kg}$ & 154.12 \\
\hline 8 & NTDA & $\mathrm{kg} / \mathrm{m} 3$ & 4067 \\
\hline 9 & SST & $\mathrm{MPa}$ & 0.679 \\
\hline 10 & PCR & $\mathrm{K}$ & 4.636 \\
\hline 11 & TCR & - & 194.5 \\
\hline 12 & PR & - & 0.518 \\
\hline 13 & TR & - & 1.661 \\
\hline 14 & $\tau$ & - & 0.412 \\
\hline 15 & $\mathrm{z}$ & $\mathrm{kJ} / \mathrm{kg}$ & 0.97 \\
\hline 16 & $\omega$ & - & 627.78 \\
\hline 17 & $\mathrm{NGDS}$ & & 0.66 \\
\hline 18 & $\eta p$ & \\
\hline
\end{tabular}

This method is adapted for natural gas, since existing techniques are based on calculations for air. The adaptation is made taking into account the heat drop in the TEU; gas density; the degree of expansion as inverse of the compression rate.

Modernization of the existing methods allows generating the correct input data for design calculations of TEU. Calculated by the developed technique thermogasdynamic and design installation parameters for a specific GDS will allow to find the optimal number of existing imported TEU or produce them in Russia, providing jobs and increasing import substitution of the units.

\section{References}

1. A. Voronin, O. Malhanov, Energy saving and water treatment, 6, (2005).

2. M. Chekardovsky, Methodology for monitoring and diagnostics of the heating system energy equipment (Nedra, $\mathrm{SPb}, 2001$ )

3. G. Krylov, A. Matveev, O. Stepanov, E. Yakovlev, Operation of gas pipelines in Western Siberia (Nedra, Leningrad, 1985)

4. O. Stepanov, M. Chekardovsky, S. Chekardovsky, Development of a comprehensive system of control, diagnosis, prediction of technical state of equipment, Scientific report inventory № 02.20. 00391, registration № 01.20. 0001269. TyumGASA, Tyumen, (2000)

5. A. Shekhtman, Gas-dynamic functions of real gases: Reference book (Energoatomizdat, Moscow, 1988)

6. V. Gurov, L. Lebedeva, G. Podvidz, E. Shcherbakova, Works of CIAM, 1296, 259-274 (1996)

7. K. Ilyukhin, B. Moiseev, M. Chekardovskiy, N. Nalobin, S. Chekardovskiy, Energy technology complexes in designing and operating equipment in heat and gas supply systems (TyumGASU, Tyumen, 2015) 
8. M. Chekardovskiy, K. Ilyukhin, A. Shapoval, S. Chekardovskiy, Upgraded algorithm for calculating the turbo - expanders gas distribution stations, Nauchnoe obozrenie, 12, 128-134 (2015)

9. M. Malkov, Handbook of Physical-technical fundamentals of cryogenics (Energoatomizdat, Moscow, 1985)

10. A. Davyidov, G. Perestoronin, V. Stulov, A. Sherstyuk, The centripetal turbine expanders (Kolos-Press, Moscow, 2002)

11. V. I. Epifanova, Low temperature radial turbine expanders (Mashinostroenie, Moscow, 1994)

12. S. Mikulin, A. Arharov, Technique of low temperatures (Energy, Moscow, 1995)

13. V. Gurov, New generation Turboexpanders, Conversion in engineering, 4, 33-35 (2006)

14. V. Kirilin, V. Syichev, A. Sheydlin, Engineering thermodynamics (Energoizdat, Moscow, 1983)

15. A. Shehtman, Gas-dynamic function of real gases (Energoatomizdat, Moscow, 1988)

16. E. Akoev, Conversion in engineering, 5, 32-39 (1997)

17. Yu. Zemenkov, V. Shalay, M. Zemenkova, Procedia Engineering, 113, 254-258 (2015)

18. Yu. Zemenkov, V. Shalay, M. Zemenkova, Procedia Engineering, 113, 312-315 (2015)

19. V. Kurushina, Y. Zemenkov, WIT Transactions on Ecology and the Environment, 190, 2, 881-888 (2014)

20. V. Antip'ev, A. Nevolin, Yu. Zemenkov, Neftyanoe Khozyaistvo - Oil Industry, 10, 46-48 (1981)

21. A. Palagin, Computer-aided design thermal schemes turbines (Naukova Dumka, Kiev, 1983)

22. A. Stepanets, Energy Turbine expanders ( Nedra-Businesscenter, Moscow, 1999)

23. A. Boyko, Yu. Govoruschenko, S. Ershov, A. Rusanov, Aerodynamic calculation and optimal design of a flowing part of turbomachinery (KhPI, Kharkov, 2002)

24. D. Anderson, Dzh. Tannehil, R. Pletcher, Computational Fluid Mechanics and Heat Transfer (Mir, Moscow, 1990) 